\title{
8 \\ Dissecting the EU response to the 'migration crisis'
}

\author{
Luca Raineri and Francesco Strazzari
}

\section{Introduction}

Europe has long been the destination of mixed-migration flows. ${ }^{1}$ Since the early 2000s, the regulation of these flows has been at the core of EU policies vis-à-vis neighbouring countries. The ENP promoted regional economic integration and institutional convergence alongside the hardening of its external borders and more stringent provisions tackling irregular migration. Coupled with the adoption of bilateral border cooperation treaties - especially between southern EU member states and southern EU neighbours - these measures have contributed considerably to keeping irregular migration to the EU under control (UNODC, 2011).

From 2011 onwards, the disruptive reconfiguration of the EU's southern neighbourhood brought about by the so-called 'Arab Springs' and their aftermath first challenged and eventually destabilised this framework. In particular, uncertain political transitions and the violent conflicts that flared up in Syria and Libya resulted in increased border porosity and large displacement numbers. The EU became a target for mixed migratory flows on an unprecedented scale: the peak was reached in 2015 , when more than one million migrants, asylum-seekers and refugees reached the EU irregularly across the Mediterranean Sea and the Balkan Peninsula. In overall terms these figures are bigger than those of refugees that reached Europe in the mid 1990s, at the apex of the wars in the former Yugoslavia, which was often depicted as Europe's worst refugee crisis since World War II.

The most conspicuous stream of this flow was observed across the Aegean Sea between Turkey and Greece, where more than 
850,000 migrants - largely of Syrian, Iraqi and Afghan origin transited in 2015. However, from March 2016 the passing of a controversial EU-Turkey 'Deal' ${ }^{2}$ helped drastically reduce mixed migration across South-Eastern Europe. Along the so-called Central Mediterranean Route (CMR), instead, mixed migratory flows proved steadier and more resilient: between 2013 and the first half of 2017, more than half a million people crossed the Mediterranean Sea from Libya to Italy. These migrants and asylum-seekers came largely from sub-Saharan Africa, including an overall amount of more than 100,000 Eritreans, ${ }^{3}$ 85,000 Nigerians and 30,000 Gambians. Throughout the same five-year period, the requests for international protection filed in Italy boomed to 427,000, dwarfing the total of 317,000 in the preceding twenty-seven years between 1985 and 2012 (Geddes, 2018).

The drastic scale-up of mixed migratory flows from the southern neighbourhood into the EU put a considerable strain on EU member states' capacity of coping and absorption. Capturing European audiences' growing concern for a phenomenon that appeared as spiralling out of control, in a period that was marked by a series of jihadist terror attacks perpetrated on European soil, the German Chancellor Angela Merkel alerted that the 'asylum issue ... would preoccupy Europe much, much more than the issue of Greece and the stability of the euro' (Westcott, 2015). At the same time, the quantitative change - that is, 'large numbers' and fears of their impact - brought about a qualitative shift in how the phenomenon came to be imagined and apprehended. Media and policy discourses have increasingly addressed these dynamics in terms of a European 'migration' and/or 'asylum' 'crisis' (Berry et al., 2015). This framing, albeit contested (Jeandesboz and Pallister-Wilkins, 2016), proved performative in shaping perceptions and prompting demands of swift responses by European leaders. Though, the multifaceted nature of the 'migration crisis' - and the polysemy of a designation that encompasses humanitarian, security, economic and identity concerns - made the identification of the most appropriate response strategy a highly divisive question across Europe.

Taking this inherent ambiguity as a starting point for our investigation, our contribution re-traces the processes that have led to the framing of an 'EU migration crisis' and to the adoption of the 
specific 'crisis response' measures. To this end, the first part of the chapter incorporates the methodological insights of securitisation studies (Buzan et al., 1998) and process-tracing (Bennett and Checkel, 2014) to unearth the complex combination of interests and concerns allegedly threatened by the rapid escalation of Europebound mixed migration according to different stakeholders.

The second part examines the specific crisis response approach that underpins the variety of tools and measures adopted by the EU to cope with the 'migration crisis'. To do so, we build on recent developments in peace studies (Mac Ginty et al., 2016; Richmond et al., 2016). We outline three approaches to crisis response, inspired by different traditions of social science: a realist response (i.e., crisis management), a structuralist response (i.e., crisis resolution) and a liberal response (i.e., crisis transformation). We define crisis management as primarily concerned with the stabilisation or containment of a crisis. It 'regards the state with its border regimes and defence mechanisms as a bulwark against negative effects of security interdependence' with the aim to 'prevent crises from spreading, destabilising regions or inflicting harmful repercussions on the EU. Crisis management works through short-term interventions, but rejects long-term engagement with the underlying causes of the crisis' (Richmond et al., 2016: 13-14). For its part, crisis resolution purports the ambition to resolve the crisis by tackling its root causes. These are typically found in the structural constraints that stifle individual needs and jeopardise the achievement of a positive peace (Galtung, 1969), such as economic marginalisation, bad governance and different forms of insecurity. Lastly, crisis transformation is focused less on tackling the conditions that made the crisis possible than on considering the long-term impact of the crisis and seeking to accommodate those new realities while at the same time addressing the crisis 'conditions of possibility' at structural level. Crisis transformation thus aims to cultivate resources such as resilience, recognition, ownership and legitimacy, that help a society cope with stressors and disruptions even when technocratic aid from abroad fades away, in order to ward off negative long-term effects of short-term crisis response measures.

The broader strategic framework of the EU provides little and somewhat contradictory - indications about the actual 
orientation of the EU crisis response. On the one hand, the general guiding principles of EU crisis response - such as conflict and context sensitivity, local ownership, human rights and humanitarian obligations, comprehensive approach to security, etc. (Pirozzi, 2013) - are more in line with crisis transformation. On the other hand, the review of the ENP - that the crises in the Mediterranean contributed to prompting (Ivashchenko-Stadnik et al., 2017) acknowledges the trade-offs between the promotion of democratic norms and the pursuit of stability: the new ENP's (European Commission and HR/VP, 2015) manifest leaning towards the latter demonstrates the toning down of the EU normative engagement and a realist shift favourable to a crisis management approach (Raineri and Strazzari, 2019). Half-way between the two, the 2016 EU Global Strategy for Foreign and Security Policy (EEAS, 2016a) purports to uphold both stabilisation and societal resilience.

These observations bring to the fore the hypothesis that the actual crisis response approach favoured by the EU may stand out more clearly within narrower policy sectors. The EU response to the migration crisis provides a valuable case study, owing to both its specificity and wide-ranging, cross-cutting influence. The tripartite analytical framework herein outlined provides the basis to ascertain whether a shift to crisis management, stabilisation and containment can be observed in the EU's dealing with its neighbourhood (Pomorska and Noutcheva, 2017) in the domain of migration policies, too.

We choose to narrow down our empirical analysis to the 'migration crisis' unfolding along the CMR so as to better illuminate the connections and contradictions between EU migration policies and the responses to the Libyan security crisis, a scenario in which unlike elsewhere - for example, Syria - the EU did and does play a significant role. The analysis of policy documents is compounded by the qualitative evidence collected through 60-plus interviews with EU officers, UN staff, members of international organisations and NGOs, as well as Libyan, Malian and Nigerian state officials and civil society representatives. Interviews were conducted in Tunis, Libya (remotely), Bamako, Niamey, Agadez and Brussels between February 2017 and November 2018, also in the framework of the EUNPACK project. 


\section{Framing the 'EU migration crisis'}

On 19 April 2015, a boat ferrying migrants and asylum-seekers from Libya to Italy shipwrecked off the shore of the island of Lampedusa, killing more than eight hundred people in what the UNHCR later defined 'the gravest humanitarian disaster in recent times' (Bonomolo and Kirchgaessner, 2015). While political concern about cross-Mediterranean migratory flows had been brewing for some time, this tragic event became the trigger that brought the EU to seize cross-Mediterranean migrations as a priority issue and devise a coordinated response. Given the swift pace of the events that followed, one can conjecture that the EU response had been at least partly planned in advance, and that the tragic fatality provided an opportunity for it to gain steam.

The day after the Lampedusa shipwreck, on 20 April 2015, a joint Foreign and Home Affairs Council was convened to discuss the event. In a joint statement, EU HR/VP Federica Mogherini and the Migration and Home Affairs Commissioner Dimitris Avramopoulos defined the situation a 'crisis' requiring urgent reaction, and introduced a ten-point plan to tackle it (the so-called Mogherini Plan, see European Commission, 2015a). Implicitly drawing on the Council's decision to foster a comprehensive approach to security (Council of the European Union, 2013), the plan called for a coordinated and enhanced mobilisation of all relevant EU instruments and resources, including Frontex (European Border and Coast Guard Agency), EASO, EUROPOL, EUROJUST, EEAS Delegations and CSDP missions.

A few days later, on 23 April 2015, a Special Meeting of the EU Council elaborated on the Mogherini Plan and committed to a number of measures to 'increase search and rescue possibilities', 'combat the smuggling and trafficking of human beings', 'tackle the root causes of illegal migration', and 'reinforce internal solidarity' and burden-sharing with frontline EU member states. Noteworthy, the Council took a more cautious attitude, and qualified the situation in the Mediterranean as 'a tragedy', and 'an emergency', but never as 'a crisis' nor as 'a threat'. The word security was never mentioned in the Council's conclusions, which nevertheless noted that 'instability in Libya create[d] an ideal environment for the criminal activities of traffickers' (Council of the European Union, 
2015a). The martial tone, however, immediately resurfaced in the remarks that Avramopoulos addressed to the Council: the commissioner claimed that 'Europe is declaring war on smugglers' (European Commission, 2015b).

The concern for comprehensiveness prompted the Council's invitation to systematise the approach endorsed for the CMR on a broader scale. As a result, the Commission issued a renewed EU Agenda on Migration on 13 May 2015: this new release updated and replaced the overarching framework governing EU external migration and asylum policy since 2005 (i.e., the Global Approach to Migration and Mobility - also known as GAMM). The new Agenda introduced a number of detailed measures to meet the ambitious objectives spelt out in the conclusions of the April Special Meeting of the EU Council: among them, military and police naval operations, external interventions to tackle migration flows upstream in the countries of origin and transit, the strengthening of EU external border controls and data collection systems, the so-called 'hotspot' approach, the review of the Dublin system for asylum applications processing, schemes for asylum-seekers' relocation, resettlement or return, and the promotion of legal migration pathways (Geddes, 2018). At the same time, the EU Agenda on Migration also moved the securitisation of migration one step further. The Agenda repeatedly defined the situation in the Mediterranean as a 'crisis' affecting European border security and to be dealt with through security means, first and foremost CSDP missions (European Commission, 2015c). It also added that 'every crisis will be different, but the EU needs to heed the lesson and be prepared to act in anticipation of a crisis, not just in reaction' (European Commission, 2015c: 11).

Building on the indications of the Council, the Commission and the Agenda on Migration, the HR/VP immediately requested the Crisis Management and Planning Directorate (CMPD, emphasis added) of the EEAS to develop a Crisis Management Concept (CMC, emphasis added) putting forward some options for a possible CSDP mission to fight migrant smuggling in the Mediterranean (EEAS, 2015). While the crisis-jargon was gaining momentum, it is worth noting that CMCs should theoretically have drawn on a respective PFCA issued by the EEAS Political and Security Committee. Since no PFCA on migration existed then, the rule was 
circumvented by relying on the 2014 PFCA for Libya (EEAS, 2014). This move ensured a little noticed - albeit crucial - attention shift: from a Libyan crisis to a migration crisis. This, however, remained implicit and was never clearly spelt out: the new crisis management concept did not qualify migration as 'a crisis', but only as 'a situation with very serious implications for the EU [which] requires urgent action' (EEAS, 2014: 3), also because of the 'need to prevent links between criminal networks and terrorist organisations' (EEAS, 2014: 6).

The fear of a crime-terror nexus therein articulated, however, seemed to rely on poor empirical evidence (Toaldo, 2015), and in fact it was entirely absent in the Libya PFCA (EEAS, 2014). EEAS officials subsequently acknowledged that 'migration and terrorism were amalgamated a bit too quickly', and admitted that they could not 'be sure whether there are actual links between terrorism and migrant trafficking' (quoted in Ivashchenko-Stadnik et al., 2017: 29). Whenever asking themselves whether the nexus existed, they concluded that the answer is not easy to find. Nonetheless, assuming the existence of a crime-terror connection eased the resort to emergency measures for responding to security 'crises' in the face of a migration 'issue'. The decision-making process was thus streamlined, and the naval CSDP mission EUNAVFOR MED - Operation Sophia was approved in the record time of a couple of months from the Lampedusa shipwreck, on 22 June 2015. Its mandate revolved around the primary goals 'to disrupt the business model of human smuggling and trafficking networks in the Southern Central Mediterranean and prevent the further loss of life at sea' (EEAS, 2017).

One week after the launching of Operation Sophia, the Council issued a note in view of the preparation of the Valletta Summit on Migration. Announced in the Agenda on Migration, the Summit was designed to gather European and African leaders in Malta to coordinate the implementation of EU migration policies' external dimension. In the note, the Council studiously avoided mentions of 'crisis' and 'security', while the situation of migrants in the Mediterranean was repeatedly defined 'a tragedy' (Council of the European Union, 2015b). Similar circumspection can be found in the phrasing of the main concluding documents which were issued a few months later at the Valletta Summit - that is, the Political Declaration and 
the Action Plan. ${ }^{4}$ Here, the notions of 'crisis' and 'in/security' were not referred to in relation to the phenomenon of large-scale migration per se, but to its root causes. In the outputs of the Valletta Summit, security is present in terms of human security (of migrants, to be preserved), food security (and lack thereof as one of the root causes of migration) and rule of law, while the commitment to the respect of human rights and humanitarian obligations is emphasised upfront. The Summit also decided to set up a new aid instrument aimed to provide a rapid, flexible and effective response to the migration issue, now described as an 'emergency': the EUTF 'for stability and addressing root causes of irregular migration and displaced persons in Africa' (European Commission, 2015d: 1).

The strategy outlined at the Summit can be considered the last step of the intense policy-making season inaugurated by the Lampedusa shipwreck of April 2015. The subsequent months were largely devoted to the implementation of the measures announced, with few unexpected additions. The process-tracing of these developments highlights that the scale-up of mixed migratory flows across the Mediterranean Sea triggered a proliferation of policies, strategies and new instruments by the EU in mid 2015. However, the subject matter was subject to considerable oscillation: the phenomenon to be addressed was qualified as a 'crisis', a 'tragedy', and an 'emergency'. As a preliminary observation, the Commission seemed to be more eager than the Council to securitise the migration issue, and it did so by tying it to notions of crisis, security and threat. Exploratory explanations for this may include the Commission's determination to emphasise the salience of the Mediterranean issue in order to elicit action by more recalcitrant member states; the Council's inherent collective action problem which tends to rule out radical options (Hampshire, 2016); or perhaps, more trivially, the Commissioners' national affiliation to countries more directly exposed to the rise of trans-Mediterranean mixed migration.

Be it as it may, the mobilisation of the concept of crisis was soon subsumed into a field of political struggle, stirring controversies. $\mathrm{UN}$ agencies working on migration questioned the appropriateness of labelling the EU migration issue a 'crisis', noting that in the same years several countries less resourced than the EU had been targeted by much larger flows of migrants and asylum-seekers (Miles, 2018). Some human rights organisations accused European leaders of 
cynically 'manufacturing' the so-called 'migration crisis' for political gain, urging them to speak instead of a political crisis prompted by large-scale migratory flows (de Bellis, 2019). Even the European Commission eagerly embraced the 'crisis' framing around 2015-16, only to denounce that enduring perceptions of a 'migration crisis' in 2018-19 were fuelled by 'fake news' and 'misinformation' (Rankin, 2019).

One could argue that this very polarisation, underpinned by calls for radical changes in EU migration policy, is in itself indicative that the migration issue fuelled a veritable crisis in the EU. According to peace studies scholarship, in fact, a crisis can be defined as 'a serious incident or set of incidents that culminates in socio-economic and/ or political instability, generating strong political pressure for a radical change.... Crises do not need to involve opposing military forces, but are bound to polarise political environments by unleashing political opposition to the intended crisis response' (Mac Ginty et al., 2016: 10). Transnational in nature, the 'migration crisis' seemed qualitatively different compared to other crises which were looming at the horizon of the EU at the same time, because of its inherent capacity to transcend the domestic-international dichotomy and generate tangible manifestations affecting Europeans' communities and daily lives.

While the framing of the migration issue as a crisis gradually made its way in political and security discourses, however, the specific nature and object of the crisis - that is, the referent object in the securitisation jargon - remained largely underspecified. Very often the iterations of the 'migration crisis' trope failed to specify what the crisis actually threatened, and therefore what crisis response mechanisms should protect. In some instantiations, the 'migration crisis' seemed to be articulated in humanitarian terms, eliciting the response to 'save lives at sea'. In other cases, and especially in iterations by the Commission, the crisis seemed to refer primarily to the escalation of transnational security threats such as smuggling networks, organised crime and terrorism. From this point of view, the crisis seemed to require a more muscular response including hardened border security, CSDP missions, and the fight (or 'war', in Avramopoulos's ineloquent wording) against migrant smugglers. Furthermore, soaring mixed migration flows prompted fears that the migration crisis would exacerbate the enduring economic crisis, overburdening the 
already stretched welfare system of southern European countries. It was also argued that the migration crisis, and the politicisation thereof, foreshadowed a deeper normative crack involving an existential crisis, whereby the rise of populist and xenophobic parties on the extreme right of the political spectrum fuelled nationalist sentiments and identity politics which, in turn, threatened the multilateralist orientation, if not the very survival of the EU (Hampshire, 2016). In a country like Italy, at the forefront of arrivals along the CMR, the Minister of Interior went as far as to express fear for the survival of democracy (La Repubblica, 2017). From this perspective, EU leaders may have favoured crisis response approaches primarily aimed to do as little harm as possible to election results, pursuing quick-fix solutions more attuned to the anxieties of their constituencies than to the needs of vulnerable groups (Loschi et al., 2018). These developments highlighted in unprecedented ways the rising tensions between the interests of national political elites, and the EU institutional architecture.

The use of the concept of 'crisis' with reference to the large-scale mixed migration in the Mediterranean can therefore be seen as clear illustration of how analytically loose the public debate was. This circumstance may be seen as convenient, in as much as the considerable - albeit implicit - spectrum of variation of the crisis's referent object could contribute to bridging consensus gaps among actors that are otherwise driven by diverging interests and concerns. From this perspective, the framing of migration policies in terms of crisis response could be said to amount to a case of 'constructive ambiguity', so common in EU policy-making (see, for instance, Jegen and Merand, 2014; Cusumano and Hofmaier, 2019). In this light, one should probably shift the analytical focus away from discursive framings, and consider instead how crisis response measures were implemented in practice. The investigation of the crisis at the response level can in fact provide valuable indications about the changing nature of the EU's actorness in crisis situations.

\section{Responding to the crisis}

On paper, the responses to the 'migration crisis' adopted by the EU entailed a variety of measures in pursuit of different objectives, 
including enhanced humanitarian action to save lives at sea; the strengthening of EU external borders to contain cross-border threats; the stepping-up of security coordination to disrupt migrant smuggling; the development efforts to tackle the root causes of migration; and the review of EU asylum policies to help frontline member states address the high volume of arrivals. Subsequent reports noted however that some of these measures have been implemented only poorly, if at all. Beyond the realm of discourses, then, the analysis of how EU migration policies have been implemented in practice can help illuminate the specific modalities and inherent tensions of the EU response to a migration issue framed as a crisis.

The different approaches to crisis response outlined in the introduction - crisis management, crisis resolution and crisis transformation - provide a valuable framework to drive the observations and categorise the cacophonic field of security practices. Crisis management arguably encompasses a variety of interrelated security practices aimed at stepping-up border security, promoting stabilisation operations, fighting cross-border networks such as - in this case migrant smugglers, and ensuring humanitarian protection at home with a limited commitment to the spreading of such norms abroad. On the other hand, responses to the migration crisis addressing primarily the needs of migrants and asylum-seekers who are forced to leave their countries of origin should be categorised as empirical manifestations of a crisis resolution approach. These may include measures to foster job creation, socio-economic development, good governance, accountability, rule of law and conflict resolution. Lastly, the strengthening of legal guarantees, the adoption of multilateral burden-sharing measures ensuring long-term sustainability, the promotion of civil society, and the fostering of capacity-building incorporating bottom-up perspectives and local knowledges, all exhibit a transformative approach in responding to migration.

These three approaches are not necessarily incompatible with each other. At first sight, the actual EU response to the migration crisis may seem adherent to all of them, at least in part. With a view to providing a fine-grained assessment of the different response approaches' relative weight in the overall EU response to the migration crisis, we analytically disentangle three distinct domains in our analysis: migration and development, humanitarian action, and border policing. 


\section{Migration and development}

The focus on the nexus between migration and development is a longstanding feature of EU policy-making (see, for instance, Sinatti and Horst, 2015). In light of the expanding range and scope of policies and instruments designed to tackle the root causes of migration through enhanced development efforts, one may be tempted to conclude that a crisis resolution type of approach inspired the EU response to the migration crisis. A closer look, however, reveals some important inconsistencies between the crisis resolution template and the post-2015 articulation of the migration-development nexus by the EU.

One notices a marked shift in the aims pursued by the EU external action in these domains, which has turned the alleged nexus upsidedown. Strategic documents issued before the migration crisis used to emphasise how migration could be beneficial to the achievement of development goals. For instance, the 2006 European Consensus on Development set out to 'make migration a positive factor for development, through the promotion of concrete measures aimed at reinforcing their contribution to poverty reduction, including facilitating remittances and limiting the "brain drain" of qualified people' (European Commission, 2006: 24). Similarly, the 2005 Commission's Communication on Migration and Development stressed the EU ambition to 'improv[e] the impact of migration on development' (European Commission, 2005: 3). Both documents, alongside the GAMM and the Lisbon Treaty issued in those same years, recalled the importance of fostering policy coherence for development. More recent strategies, by contrast, overturn the nexus, and exhort to make development aid functional to EU migration goals, first and foremost the curbing of irregular migration. For instance, the 2016 Partnership Framework on Migration - which builds on the Agenda on Migration and shapes the New European Consensus on Development (European Commission, 2017) - states plainly that

coherence between migration and development policy is important to ensure that development assistance helps partner countries manage migration more effectively.... Positive and negative incentives should be integrated in the EU's development policy, rewarding those countries that fulfil their international obligation to readmit their own nationals, and those that cooperate in managing the flows of irregular migrants. (European Commission, 2016: 9) 
This shift indicates a clear departure from the needs-based perspective of crisis resolution.

The EUTF provides another eloquent illustration of these trends. The EUTF is usually presented as the EU signature tool to tackle the root causes of migration through development assistance. However, it has been noted that the largest share of EUTF resources are not added to, but diverted from more traditional EU aid budgets, such as the European Development Fund and the Development Cooperation Instrument. The main change in the process is that the EUTF largely derogates from OECD best practices, most notably in terms of management transparency, alignment with national development strategies, local ownership, civil society involvement and needsbased assessment. As a result, beneficiaries of EUTF-sponsored projects are frequently identified based on their migratory status, rather than on their needs (Oxfam, 2017).

The actual allocation of development funds follows the same orientation. This is most visible in partner countries deemed strategic for the external governance of mixed migratory flows. In Libya, out of an overall EU budget for bilateral assistance amounting in early 2018 to $€ 354$ million, pooled from different instruments (EEAS, 2018), the largest share was devoted to programmes of migrants' repatriation and border management (Loschi et al., 2018). In Niger, where in the same years the overall EU development aid exceeded $€ 900$ million (Zandonini, 2018), representing 45 per cent of the country's whole national budget (Bergamaschi, 2017), the largest share of EU funds supported socio-economic development (Molenaar et al., 2018). However, it is noteworthy that it is only after the adoption of the Partnership Framework by the EU that Niger started to fight migrant smuggling, an activity that was otherwise locally seen as legitimate and beneficial (Raineri, 2018). In the same vein, the broader EU engagement in the Sahel adjusted its priority from development, as enshrined in the 2011 EU Security and Development Strategy in the Sahel, to migration and border controls, 'following the EU mobilisation against irregular migration and related trafficking' (EEAS, 2016b).

Overall, this analysis suggests that EU response to the migration crisis through development aligns poorly with the requirements of a crisis resolution type of approach. This is illustrated most clearly by the de-priorisation of migrants' and asylum-seekers' needs in the 
decisions over budget allocations. Similarly, the top-down direction of development strategies and the curtailment of local ownership and civil society's role is conflicting with crisis transformation. Instead, the transfer and/or subjection of resources earmarked for development to the implementation of border protection measures is more consistent with a realist-inspired approach to crisis response - that is, crisis management.

\section{Humanitarian action}

While the Mediterranean Sea hit the headlines of journalistic and scholarly reports as the deadliest border to cross for migrants worldwide (International Organization for Migration, 2017), many of the EU post-2015 migration policies purported the ambition to 'save lives at sea'. This suggests the importance of humanitarian concerns in the framing of the EU's overall response to the migration crisis. At the same time, critical scholarship has stressed the ambiguity of such humanitarian commitment, which can contribute not only to 'sav[ing] lives', but also to the entrenchment of exclusionary regimes and of bordering practices (Pallister-Wilkins, 2015; Cuttitta, 2018). Mirroring this ambivalence, the focus on humanitarian action shares some key features with all the approaches to crisis response detailed above. An in-depth analysis of EU humanitarian response is therefore required to ascertain whether this was more intended to manage the consequence of the migration crisis, address its root causes in situations of emergency, or build resilience by extending humanitarian guarantees.

One notices that the fight against migrant smuggling has generally taken precedence over humanitarian concerns in EU crisis response. In the countries crossed by mixed migratory flows, the criminalisation of irregular migration encouraged by the EU has reportedly jeopardised the capacity of EU-sponsored humanitarian organisations to gain access to migrants and asylum-seekers, and to provide assistance to those in need (Molenaar et al., 2018). Even more explicitly, the CSDP-mission Operation Sophia was deliberately designed to minimise deployment in humanitarian operations, in spite of its mandate to 'to disrupt the business model of human smuggling' and 'prevent the further loss of life at sea'. On several occasions, EUNAVFOR MED strategic documents (EEAS, 2015, 
2018) reiterated that SAR activities were not part of Operation Sophia's core mandate, while the mission's crisis management concept seemed to imply that EUNAVFOR MED's subjection to humanitarian (and human rights) obligations would be only contingent (Ivashchenko-Stadnik et al., 2017).

By contrast, the EU and its member states progressively outsourced SAR activities to the Libyan authorities. Since the second half of 2016, the Political and Security Committee authorised EUNAVFOR MED to engage in the capacity-building of the Libyan coastguard, with increasing EUTF resources made available to this end. In June 2017 the Commission invited the Italian coastguard to help the Libyan authorities set up a Maritime Rescue Coordination Centre in Libya (EEAS, 2017). In the meantime, humanitarian NGOs who had stepped in to address the growing needs in rescue operations were subjected to increasing pressures by frontline member states with the steady backing of Brussels - conceivably meant to deter SAR activities by non-state actors (Loschi et al., 2018).

The strategy of externalising SAR operations was arguably a compromise between, on the one hand, the fear that Europe-bound rescue operations could incentivise irregular migrants to undertake dangerous sea-crossings and, on the other hand, the illegality under EU human rights law of returning rescued migrants and asylumseekers to Libya by European actors, be they public or private. This approach, however, proved inconsistent with the humanitarian imperative of saving lives. The number of migrants reported dead in the attempt of crossing the CMR increased markedly between 2015 and 2016, from 3,149 to 4,581. The absolute decline observed in the subsequent years - to 2,853 in 2017 and 1,314 in 2018 - was compounded by a drastic rise in the proportion of deaths over the attempted crossing, peaking to approximately 1 in 10 in $2018 .^{5}$ This was a rate far higher than had been observed at any point during the crisis, prompting scholars to condemn EU humanitarian engagement as hypocritical (Cusumano, 2019). Although more difficult to quantify, the fatality rates appeared to soar also in the downstream segment of the migratory routes targeted by EU anti-smuggling measures, stirring the concerns of humanitarian actors (Danish Refugee Council, 2016).

At the same time, through the externalisation of SAR and humanitarian action to Libyan actors, the EU has indirectly promoted the 
massive resort to unsafe detention schemes for the management of irregular migration. The systematic abuses perpetrated on migrants and asylum-seekers documented in Libyan detention centres offer a clear illustration of this (UNSMIL and OHCHR, 2016), that the EU has been embarrassingly reluctant to acknowledge and condemn. This brought a variety of actors, including human rights organisations (Amnesty International, 2017), humanitarian NGOs (Liu, 2017) and UN agencies (OHCHR, 2017), to denounce the EU's perceived eagerness to compromise on its normative principles, exposing EU crisis response to unprecedented levels of criticism. Since late 2017, the EU has sponsored the humanitarian evacuations of vulnerable migrants trapped in Libyan detention centres. These, however, proved too limited in scope to offer more than a palliative response to a much more encompassing problem, especially as long as the underlying issue of migrants' legal status in the countries of transit is not adequately addressed (Molenaar and Ezzedine, 2018).

Overall, these observations highlight that, in spite of magniloquent claims, the humanitarian imperative to save lives within the EU response to the migration crisis was at best auxiliary to, if not contingent on, the fulfilment of other priorities. From this perspective, in isolation from a stronger determination to tackle broader insecurities and rule of law issues in third countries, EU humanitarian action cannot be seen as conducive to a resolution of the migration crisis. This is also because - by problematically equating migrant smuggling not to a means but to a root cause of irregular migration - the EU has appeared to neglect the needs of migrants and asylum-seekers. Furthermore, the deliberate curtailment of the role of civil society, the short-term temporality of the interventions, and the failure to extend the migrants' and asylumseekers legal guarantees - whether in the EU or in third countries - suggest that EU-sponsored humanitarianism has had little to do with a transformative approach to the migration crisis. True, the emphasis on capacity-building may suggest otherwise. However, it should be noted that while this was frequently justified with humanitarian arguments, de facto capacity-building predominantly targeted law enforcement actors, with the purpose of supporting border management and containing the spill-over of the crisis. In conclusion, then, EU humanitarian action seemed more 
attuned with the (limited) ambition of a crisis management agenda than anything else.

\section{Border policing}

The stepping-up of border policing measures represents one of the most prominent domains of the crisis response by the EU. The migration crisis prompted in fact a massive escalation of EU investments in this domain, both at EU external borders and in third countries of transit of mixed migratory flows to Europe. Frontex, for instance, saw a sevenfold increase in its budget as a direct result of the migration crisis, from $€ 15.7$ million in its first full year of operation in 2006 to $€ 114$ million in 2015 (Hampshire, 2015: 549), and the Agenda on Migration prospected a further inflation to more than $€ 300$ million in 2020 . The external dimension of border policing has expanded concomitantly. One report found that the ENP budget earmarked for border externalisation has boomed from $€ 59$ million in 2003, to $€ 15.4$ billion in 2014-20 (Akkermann, 2018). If one looks even further afield along migratory routes, the estimated costs of EU efforts to tighten border controls and deter irregular migration in third countries have reportedly exceeded $€ 15$ billion only in the eighteen months that followed the declaration of the migration emergency (Overseas Development Institute, 2016).

Prima facie, such a focus on border policing lends credibility to the hypothesis that the EU response was primarily shaped by a crisis management agenda, with its focus on state security and threat containment. Corroborating this interpretation, a considerable emphasis on the fight against migrant smuggling and trafficking (often conflated without further specification) through police and security means is a common thread tying together the Mogherini Plan, the conclusions of the Special Meeting on migration of the EU Council, the Agenda on Migration, the very deployment of EUNAVFOR MED - Operation Sophia, as well as a remarkable share of the EUTF allocations. One could even argue that, through the Agenda on Migration and the Partnership Framework, the fight against migrant smuggling was not only streamlined, but it also came to subsume and reconfigure the overall EU engagement with third countries in North Africa and the Sahel, as for instance the case of Niger illustrates. 
At the same time, though, border policing is not necessarily incompatible with alternative approaches, as long as it integrates the needs of vulnerable groups and the knowledge of local actors, and it is designed to contribute primarily to good governance and/ or societal resilience. Available studies however suggest that these ambitions were only marginally integrated in EU's growing focus on border policing. The genesis of Operation Sophia is particularly telling in this sense: at the peak of the crisis, the transformative ambition to foster an integrated border management in Libya was (provisionally) set aside to give priority to more muscular containment measures in order to prevent the spill-over of the crisis through the strengthening of the maritime border (Ivashchenko-Stadnik et al., 2017). In the extended neighbourhood, the EU has urged Sahelian countries to adopt anti-smuggling strategies before more encompassing migration strategies, and border security strategies before more comprehensive national security strategies. The precedence of the particular (security-oriented) over the general suggests a turning of the logic of a coherent support to good-governance upside-down. Furthermore, the EU has in many cases demonstrated its eagerness to turn a blind eye on the authoritarian and/or criminal drift of third countries' authorities in exchange for their cooperation on migration and border policing. From this perspective, EU crisis response may have contributed to empowering unaccountable rulers and cementing predatory practices stretching from capital cities to remote border outposts of partner countries. The cases of Mali (Lebovich, 2018), Niger (Raineri, 2018), Sudan (Molenaar et al., 2018), Turkey (Pierini, 2018) and Libya (Micallef et al., 2019) provide ample illustration of how the stress-test of a migration crisis (or perception thereof) has diluted the EU ambitions to promote good governance and liberal statebuilding.

Internally, the EU has by and large failed to adopt the reform needed to ensure the EU's own greater resilience through a more sustainable system of integrated border management, asylum applications processing, and burden-sharing. Owing to the reluctance of some EU member states, the relocation scheme enshrined in the Agenda on Migration was only poorly implemented, in spite of its rather limited ambitions (Geddes, 2018), while the reform of the Dublin regulation governing the asylum applications examination and processing has lagged behind. As the stalemate on these issues 
fuelled mutual distrust and suspicions across the EU, the strengthening of EU external border policing soon emerged as one of the few domains where a modicum level of agreement and progress could be reached.

All in all, these observations suggest that border policing measures have provided one of the most enduring, consistent and expanding domains of the EU response to the migration crisis. However, it is only the interpretation and implementation of these measures in the rather conservative terms of crisis management rather than crisis resolution or crisis transformation - that secured the needed levels of convergence among the disparate interests of EU institutions, EU member states and third countries' elites. The inability to address the more structural issues and longer term impacts of border protection, though, may be self-defeating and unsustainable as critics pointed out (Lebovich, 2018).

\section{Concluding observations}

With the reshuffling of the Mediterranean politics that followed the Arab Springs, the rapid surge of mixed migratory flows to Europe has tested the coping capacity of the EU and its member states. However, the very framing of this situation as a 'crisis', and the securitisation thereof, has not been straightforward, but uneven and contested. Re-tracing the discursive steps underpinning the mobilisation of the 'migration crisis' narrative has led us to note the considerable degree of analytical looseness of this framing (what the crisis is about) and of its referent object (what the crisis is threatening). We have argued that this could be seen as a case of 'constructive ambiguity' to bridge consensus gaps across different configurations of interests and concerns.

The ambiguity of the discursive framing has prompted the shift of the analytical focus to crisis response practices. We have therefore investigated in depth the specific strategies and measures put in place by the EU to respond to a migration issue defined as a crisis, looking in particular at the domains of migration and development, humanitarian action, and border policing. EU migration-related measures in these domains have been compared and contrasted with the policy prescriptions of crisis management, crisis resolution 
and crisis transformation templates, in order to ascertain the relative weight of different approaches to crisis response in EU actorness. Our analysis suggests that, while on paper, EU crisis response appears to combine insights from the three approaches, in practice the EU has invested much more in the management of the migration crisis. In all the three domains analysed, the focus is predominantly on the containment of irregular migration flows rather than on addressing their structural causes or on building societal resilience vis-à-vis their long-term impacts.

As a realist approach to crisis response inspires crisis management, this finding corroborates the conclusion of recent scholarship on the overall trend of EU security posture in the last decade or so (Pomorska and Noutcheva, 2017; Belloni et al., 2019). Yet this is not merely pleonastic. Building on recent scholarship (Richmond et al., 2016), in fact, one could have expected a greater geographic differentiation of EU crisis response, whereby structuralist and transformative approaches would prevail in the EU neighbourhood, in line with the normative ambitions of the ENP, while a realist strategy focused on security, borders and centralised states would rather fit EU action in the extended neighbourhood. Our analysis highlights instead that, in the context of the 'migration crisis', the realist approach to crisis response is cross-cutting, suggesting that such a discernment between different recipients of EU crisis response is waning. Interestingly, then, uniformity between EU neighbours and neighbours' neighbours is being achieved less by spreading norms from close to distant neighbours (i.e., crisis resolution and transformation) than by generalising the approach that was originally meant for distant neighbours only (i.e., crisis management) to all third countries. This suggests that the model of crisis response that is emerging through the 'migration crisis' is underpinned by a strong process of estrangement and othering, which widens the gap between the security approaches and normative standards accepted for the EU, and for 'the rest'. Bordering, thus, manifests itself not only as a material process, but also as a symbolic one, in which analytical distinctions that are sharp and essentialised are favoured to the ones which are more nuanced and tailored.

This dissonance, however, could contribute to fading the image of the EU as a reliable supporter of the demands of democracy, good governance and accountability. As outlined in this chapter, 
such shift may involve high reputational costs for the EU. At the same time, the potential for political and security costs, too, should not be underestimated. Alternative allies may become tempting for those in the EU neighbourhood bearing demands for change, and who feel constrained between the rock of local authoritarian rulers and the hard place of EU's self-absorbed attitude. One could argue that the increasing influence of Gulf states and Russia in the EU southern neighbourhood already provides an illustration of these ongoing dynamics. Similarly, unmet demands for social and physical mobility could find an expression through transnational radical ideologies that provide a formidable challenge to both the status quo and EU values.

In other words, by indulging in the realist drift of contemporary international politics, the EU may find itself obliged to play a game it is not equipped to play, a game in which the normative weapons of the EU constitutive arsenal become dull instruments. The South-Eastern EU borderlands were crossed in the 1990s by hundreds of thousands of refugees fleeing the Yugoslav wars, a tragedy that unfolded from the Maastricht summit of 1991 onwards, marking the beginning of the EU and its foreign projection. Today, we have seen in those very same corners of Europe, thousands of Syrian refugees who were rejected, detained and abused. An ill-thought crisis response to an ill-defined migration crisis makes the need for crisis management a self-fulfilling prophecy.

\section{Notes}

1 The term 'mixed migration' is more comprehensive than that of 'migrant' or 'refugee', as it encompasses the mobility of individuals with different legal statuses. According to the 2016 UN Declaration for Refugees and Migrants, the only internationally adopted document on both refugees and migrants, mixed migration refers to cross-border 'mixed flows of people, whether refugees or migrants, who move for different reasons but who may use similar routes' (UNGA, 2016).

2 Based on the Joint Action Plan to fight irregular migration, the 'deal' passed on 18 March 2016 between the EU and Turkey has raised significant legal controversies, both vis-à-vis its legal nature - whether an international legally binding agreement or a political statement - and 
vis-à-vis its compatibility with international human rights and refugee law (Lehner, 2018).

3 It has been argued that many of those self-identified as Eritreans may in fact be Ethiopian nationals who purport an Eritrean identity to increase their chances of obtaining a refugee status in Europe (Reitano and Tinti, 2015).

4 Documents at www.consilium.europa.eu/it/meetings/internationalsummit/2015/11/11-12/ (accessed 1 February 2020).

5 Data at https://missingmigrants.iom.int/region/mediterranean?migrant_ route $\% 5 \mathrm{~B} \% 5 \mathrm{D}=1376$ (accessed 1 February 2020).

\section{References}

Akkerman, M. (2018, May) Expanding the Fortress: The Policies, the Profiteers and the People Shaped by the EU's Border Externalisation Programme (Amsterdam: Transnational Institute).

Amnesty International (2017) Libya's Dark Web of Collusion: Abuses against Europe-Bound Refugees and Migrants (London: Amnesty International, December).

Belloni, R., V. Della Sala and P. Viotti (eds) (2019) Fear and Uncertainty in Europe: The Return to Realism? (London: Palgrave Macmillan).

Bennett, A. and J.T. Checkel (eds) (2014) Process Tracing: From Metaphor to Analytic Tool (Cambridge: Cambridge University Press).

Bergamaschi, I. (2017) 'Aid in the Sahel in the 2000s: Tales of dependence and appropriation', Conference Paper, www.academia.edu/34241179/ (accessed 1 February 2020).

Berry, M., I. Garcia-Blanco and K. Moore (2015) Press Coverage of the Refugee and Migrant Crisis in the EU: A Content Analysis of Five European Countries. Report prepared for the UNHCR (UNHCR, December).

Bonomolo, A. and S. Kirchgaessner (2015) 'UN says 800 migrants dead in boat disaster as Italy launches rescue of two more vessels', Guardian, 20 April.

Buzan, B., O. Wæver and J. de Wilde (1998) Security: A New Framework for Analysis (London: Lynne Rienner Publishers).

Council of the European Union (2013) Joint Communication to the European Parliament and the Council - The EU's comprehensive approach to external conflicts and crises (Brussels: 12 December).

Council of the European Union (2015a) Special meeting of the European Council - Statement (Brussels: 23 April). 
Council of the European Union (2015b) Valletta Conference on Migration (Malta, 11-12 November) - Orientation Debate (Brussels: 30 June).

Cusumano, E. (2019) 'Migrant rescue as organized hypocrisy: EU maritime missions offshore Libya between humanitarianism and border control', Cooperation and Conflict, 54(1): 3-24.

Cusumano, E. and S. Hofmaier (eds) (2019) Projecting Resilience Across the Mediterranean (London: Palgrave Macmillan).

Cuttitta, P. (2018) 'Delocalization, humanitarianism and human rights: The Mediterranean border between exclusion and inclusion', Antipode: A Radical Journal of Geography, 50(3): 783-803.

Danish Refugee Council (2016) 'Forgotten fatalities: The number of migrants' deaths before reaching the Mediterranean', Mixed Migration Monitoring Mechanism Initiative (Geneva: DRC, June).

de Bellis, M. (2019) 'European leaders are manufacturing a "migration crisis” for political gain', Amnesty International Blog, 18 January.

EEAS (2014) 'Libya, a Political Framework for a Crisis Approach' (Brussels: EEAS, 1 October).

EEAS (2015) Working document - Crisis Management Concept (Brussels: EEAS, May).

EEAS (2016a) Shared Vision, Common Action: A Stronger Europe. A Global Strategy for the European Union's Foreign and Security Policy (Brussels: EEAS, June).

EEAS (2016b) Annual Report on the Sabel Regional Action Plan 2015/2016 (Brussels: EEAS, 23 December).

EEAS (2017) 'European Union Naval Force - Mediterranean Operation Sophia' (Rome: EEAS, 31 March).

EEAS (2018) 'Strategic Review on EUNAVFOR MED Operation Sophia, EUBAM Libya \& EU Liaison and Planning Cell' (Brussels: EEAS, 27 July).

European Commission (2006) Communication to the Council, the European Parliament, the European Economic and Social Committee and the Committee of Regions: Migration and Development: Some concrete orientations (Brussels: European Commission, 1 September).

European Commission (2006) The European Consensus on Development (Brussels: European Commission, June).

European Commission (2015a) 'Joint Foreign and Home Affairs Council: Ten point action plan on migration', Press release (Luxembourg: European Commission, 20 April).

European Commission (2015b) Speech: Remarks by Commissioner Avramopoulos at the press conference in Castille Place, Malta (Valletta, 23 April). 
European Commission (2015c) Communication to the European Parliament, the Council, the European Economic and Social Committee and the Committee of the Regions: A European Agenda on Migration (Brussels: European Commission, 13 May).

European Commission (2015d) 'Agreement establishing the European Union Emergency Trust Fund for stability and addressing root causes of irregular migration and displaced persons in Africa, and its internal rules' (Brussels: European Commission, 20 October).

European Commission and HR/VP (2015) Joint Communication to the European Parliament, the Council, the European Economic and Social Committee and the Committee of the Regions: Review of the European Neighbourhood Policy (Brussels: European Commission, 18 November).

European Commission (2016) Communication to the European Parliament, the Council and the European Investment Bank on establishing a new Partnership Framework with third countries under the European Agenda on Migration (Strasbourg: European Commission, 7 June).

European Commission (2017) The New European Consensus on Development. 'Our World, Our Dignity, Our Future' (Brussels: European Commission, June).

Galtung, J. (1969) 'Violence, peace, and peace research', Journal of Peace Research, 6(3): 167-191.

Geddes, A. (2018) 'The politics of European Union migration governance', JCMS: Journal of Common Market Studies, 56(S1): 120-130.

Hampshire, J. (2015) 'European migration governance since the Lisbon treaty: Introduction to the special issue', Journal of Ethnic and Migration Studies, 42(4): 537-553, doi: 10.1080/1369183X.2015.1103033.

Hampshire, J. (2016) 'Speaking with one voice? The European Union's global approach to migration and mobility and the limits of international migration cooperation', Journal of Ethnic and Migration Studies, 42(4): 571-586.

International Organization for Migration (2017) Four Decades of Cross-Mediterranean Undocumented Migration to Europe (Geneva: IOM, November).

Ivashchenko-Stadnik, K., R. Petrov, L. Raineri, P. Rieker, A. Russo and F. Strazzari (2017) 'How the EU is facing crises in its neighbourhood: Evidence from Libya and Ukraine', EUNPACK Working Paper D.6.1, EUNPACK project.

Jeandesboz, J. and P. Pallister-Wilkins (2016) 'Crisis, routine, consolidation: The politics of the Mediterranean migration crisis', Mediterranean Politics, 21(2): 316-320. 
Jegen, M. and F. Mérand (2014) 'Constructive ambiguity: Comparing the EU's energy and defence policies', West European Politics, 37(1): 182-203.

La Repubblica (2017) 'Minniti: "Sui migranti ho temuto per la tenuta democratica Paese"', La Repubblica, 29 August.

Lebovich, A. (2018) 'Halting ambition: EU migration and security policy in the Sahel'. European Council on Foreign Relations (ECFR) Policy Brief (London: ECFR, September).

Lehner, R. (2018) 'The EU-Turkey "deal”: Legal challenges and pitfalls', International Migration, 57(2): 176-185.

Liu, J. (2017) 'Europe is feeding a criminal system of abuse in Libya', Doctors Without Borders Blog, 7 September.

Loschi, C., L. Raineri and F. Strazzari (2018) 'The implementation of EU Crisis Response in Libya: Bridging theory and practice', EUNPACK Working Paper D.6.2, EUNPACK project.

Mac Ginty, R., S. Pogodda and O.P. Richmond (2016) 'Crises and concepts', EUNPACK Working Paper D.3.1, EUNPACK project.

Micallef, M., R. Horsley and A. Bish (2019) The Human Conveyor Belt Broken: Assessing the Collapse of the Human-Smuggling Industry in Libya and the Central Sahel. The Global Initiative Against Transnational Organized Crime and Clingendael (Geneva, March).

Miles, T. (2018) 'U.N. view on the European migrant crisis? There isn't one', Reuters, 6 July.

Molenaar, F. and N. Ezzedinne (2018) Southbound Mixed Movement to Niger: An Analysis of Changing Dynamics and Policy Responses. Clingendael CRU Report (The Hague: Clingendael Institute, December).

Molenaar, F., J. Tubiana and C. Warin (2018) Caught in the Middle: A Human Rights and Peace-Building Approach to Migration Governance in the Sahel. Clingendael CRU Report (The Hague: Clingendael Institute, December).

OHCHR (2017) 'EU "trying to move border to Libya" using policy that breaches rights - UN experts' (Geneva: OHCR, 17 August).

Overseas Development Institute (2016) Europe's Refugees and Migrants: Hidden Flows, Tightened Borders and Spiralling Costs (London: ODI, 14 September).

Oxfam (2017) 'An emergency for whom? The EU Emergency Trust Fund for Africa: Migratory routes and development aid in Africa', Oxfam Briefing Note (Brussels: Oxfam, 15 November).

Pallister-Wilkins, P. (2015) 'The humanitarian politics of European border policing: Frontex and border police in Evros', International Political Sociology, 9(1): 53-69. 
Pierini, M. (2018) 'The 2018 Turkey Regress Report', Carnegie Article (London, 14 March).

Pirozzi, N. (2013) 'The EU's comprehensive approach to crisis management' (Brussels: DCAF, June).

Pomorska, K. and G. Noutcheva (2017) 'Europe as a regional actor: Waning influence in an unstable and authoritarian neighbourhood', JCMS: Journal of Common Market Studies, 55(S1): 165-176.

Raineri, L. (2018) 'Human smuggling across Niger: State-sponsored protection rackets and contradictory security imperatives', Journal of Modern African Studies, 56(1): 63-86.

Raineri, L. and F. Strazzari (2019) '(B)ordering hybrid security? EU stabilisation practices in the Sahara-Sahel Region', Ethnopolitics, 18(5): 544-559.

Rankin, J. (2019) 'EU declares migration crisis over as it hits out at "fake news"', Guardian, 6 March.

Reitano, T. and P. Tinti (2015) 'Survive and advance: The economics of smuggling refugees and migrants into Europe’ ISS Paper 289 (Dakar: Institute for Security Studies, November).

Richmond, O.P., S. Pogodda and R. Mac Ginty (2016) 'Towards critical crisis transformation', EUNPACK Working Paper D.3.2, EUNPACK project.

Sinatti, G. and C. Horst (2015) 'Migrants as agents of development: Diaspora engagement discourse and practice in Europe', Ethnicities, 15(1): 134-152.

Toaldo, M. (2015) 'Migrations through and from Libya: A Mediterranean challenge', IAI Working Paper 15 (Rome: Istituto Affari Internazionali, 14 May).

UNGA, Resolution 71/1 (2016) 'New York Declaration for Refugees and Migrants' (New York, 10 September).

UNODC (UN Office on Drugs and Crime) (2011) The Role of Organized Crime in the Smuggling of Migrants from West Africa to the European Union (Vienna: UNODC, January).

UNSMIL and OHCHR (2016) 'Detained and Dehumanised': Report on Human Rights Abuses against Migrants in Libya (Geneva: UNSMIL, 13 December).

Westcott, L. (2015) 'Merkel: Refugees could be bigger challenge than Greek debt crisis', Newsweek, 17 August.

Zandonini, G. (2018) 'Niger: il perno instabile della politica UE nel Sahel', ISPI Commentary, 1 August. 